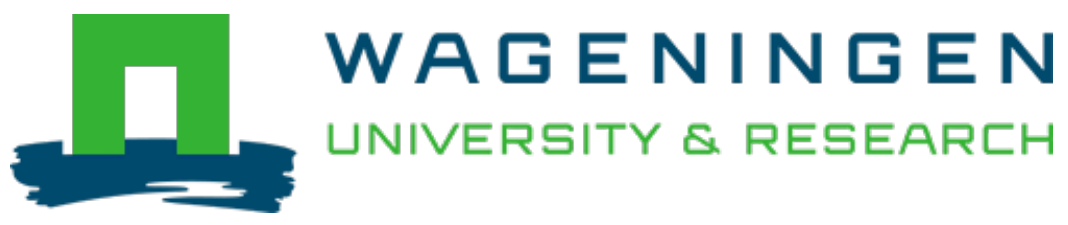

\title{
Influence of educational actions on transitioning of food safety culture in a food service context: Part 2 - Effectiveness of educational actions in a longitudinal study
}

Food Control

Mariano Zanin, Lais; Stedefeldt, Elke; Silva, Sueli Maria; Cunha, Diogo Thimoteo; Luning, P.A. https://doi.org/10.1016/j.foodcont.2020.107542

This article is made publicly available in the institutional repository of Wageningen University and Research, under the terms of article $25 \mathrm{fa}$ of the Dutch Copyright Act, also known as the Amendment Taverne. This has been done with explicit consent by the author.

Article $25 \mathrm{fa}$ states that the author of a short scientific work funded either wholly or partially by Dutch public funds is entitled to make that work publicly available for no consideration following a reasonable period of time after the work was first published, provided that clear reference is made to the source of the first publication of the work.

This publication is distributed under The Association of Universities in the Netherlands (VSNU) 'Article $25 \mathrm{fa}$ implementation' project. In this project research outputs of researchers employed by Dutch Universities that comply with the legal requirements of Article 25fa of the Dutch Copyright Act are distributed online and free of cost or other barriers in institutional repositories. Research outputs are distributed six months after their first online publication in the original published version and with proper attribution to the source of the original publication.

You are permitted to download and use the publication for personal purposes. All rights remain with the author(s) and / or copyright owner(s) of this work. Any use of the publication or parts of it other than authorised under article $25 \mathrm{fa}$ of the Dutch Copyright act is prohibited. Wageningen University \& Research and the author(s) of this publication shall not be held responsible or liable for any damages resulting from your (re)use of this publication.

For questions regarding the public availability of this article please contact openscience.library@wur.nl 


\title{
Influence of educational actions on transitioning of food safety culture in a food service context: Part 2 - Effectiveness of educational actions in a longitudinal study
}

\author{
Laís Mariano Zanin ${ }^{a}$, Elke Stedefeldt ${ }^{\text {b, }}$, Sueli Maria da Silva ${ }^{c}$, Diogo Thimoteo da Cunha ${ }^{\text {, }}$ \\ Pieternel A. Luning ${ }^{e}$ \\ a Postgraduate Program in Nutrition, Federal University of São Paulo, São Paulo, Brazil, 862, Botucatu St, Vila Clementino, São Paulo, SP, 04039-032, Brazil \\ b Department of Preventive Medicine, Federal University of São Paulo, São Paulo, Brazil, 740, Botucatu St, Fourth Floor, Vila Clementino, São Paulo, SP, 04024-002, \\ Brazil \\ ${ }^{\mathrm{c}}$ Higher Education Development Centre in Health, Federal University of São Paulo, São Paulo, Brazil, 859, Pedro de Toledo St, Vila Clementino, São Paulo, SP, 04039- \\ 032, Brazil \\ ${ }^{\mathrm{d}}$ Multidisciplinary Laboratory of Food and Health, School of Applied Sciences, State University of Campinas, 1300 Pedro Zaccaria St, Jd Santa Luzia, Limeira, SP, \\ 13484-350, Brazil \\ ${ }^{\mathrm{e}}$ Food Quality and Design, Department of Agrotechnology and Food Sciences, Wageningen University, P.O. Box 17, AA Wageningen, 6700, the Netherlands
}

\section{A R T I C L E I N F O}

\section{Keywords:}

Food safety training

Food safety behaviour

Army food service

Action research

Triangulation

Brazil

\begin{abstract}
A B S T R A C T
Recently, the food safety culture (FS-culture) gained attention as a critical factor for reducing foodborne diseases. This study investigated the effectiveness of educational actions in the transition of FS-culture in a longitudinal study using action research in an army food service, which was selected as a case. We hypothesised that the FSculture assessment might be a good starting point to develop educational actions. First, we identified the educational needs of food handlers and managers based on a FS-culture assessment, followed by the implementation of educational actions using three formats (tutored, planned, and with the managers). A previously developed mixed-method approach was used for the collection of qualitative and quantitative data, data triangulation, and an interpretation grid that was used for categorisation into reactive, active, or proactive FS-culture. The triangulated data showed that the prevailing FS-culture changed from reactive to more proactive during the longitudinal study. The educational actions changed attitudes, practices, personal relationships, and the work environment. The educational actions were effective in influencing the prevailing FS-culture and confirmed the research hypothesis. Furthermore, the mixed-method approach with the interpretation grid was useful in assessing the transition in the prevailing FS-culture. Further research may test the usefulness of other types of food services in other countries. We also recommend converting the scientific methods for FS-culture assessment into methods suitable for the use by food safety managers in food services.
\end{abstract}

\section{Introduction}

The recent food safety literature has shown that researchers remain concerned about risks in food service establishments, where the interplay between food handlers, managers, and chefs in food handling and safety is predominant (Da Cunha, De Rosso, \& Stedefeldt, 2018; De Boeck, Jacxsens, Vanoverberghe, \& Vlerick, 2019; Flynn et al., 2019). The occurrence of foodborne outbreaks, particularly in this sector, is still affecting consumer health. For example, restaurants and catering hold responsible for $75 \%$ of the number of outbreaks in the United States of America in 2016 (Centers for Disease Control, 2016) and 46\% in the European Union in 2017 (European Food Safety Authority, 2018). Therefore, there is still a need to implement effective measures to reduce the risk of foodborne diseases in food service establishments.

Many researchers proposed training as the primary measure to reduce the risk of foodborne diseases (McFarland, Checinska Sielaff, Rasco, \& Smith, 2019; Yu, Sirsat, \& Neal, 2019). The type, style, and techniques of training play an important role in the development of

\footnotetext{
* Corresponding author. .

E-mail addresses: zanin.lais@gmail.com (L.M. Zanin), elke.stedefeldt@unifesp.br (E. Stedefeldt), sueli.mari.sil@gmail.com (S.M. da Silva), diogo.cunha@fca. unicamp.br (D.T. da Cunha), pieternel.luning@wur.nl (P.A. Luning).
} 
appropriate behaviours (Medeiros, Cavalli, Salay, \& Proença, 2011; Young, Waddell, Wilhelm, \& Greig, 2020; Yu, Neal, Dawson, \& Madera, 2018; Zanin, Da Cunha, De Rosso, Capriles, \& Stedefeldt, 2017). However, several studies showed that training alone is not always an adequate precursor of behaviours or practices (Da Cunha, Stedefeldt, \& De Rosso, 2014; Ehiri, Morris, \& McEwen, 1997; Young, Greig, Wilhelm, \& Waddell, 2019; Yu et al., 2018; Zanin, Da Cunha, Stedefeldt, \& Capriles, 2015). Lin and Paez (2020) also acknowledged that training is one of the biggest challenges in food safety. This situation underpins the need for new concepts and points of view for training.

In 2014, Griffith (2014, p.39) introduced a broader concept of food safety training. This author defined 'education' as a planned process to change knowledge, attitudes, and especially skill behaviours (i.e. the ability to do something) through a learning experience. His education concept includes a comprehensive work and social framework and encompasses other activities than just handling food. Moreover, Stedefeldt et al. (2015) stressed that the educational approach must contemplate, besides formal training, social relationships, perceptions, feelings, and experiences that shape the behaviour. Such an educational approach encompasses actions aimed at developing professional skills through continuously involving previous knowledge and experiences and exchanging experience between the people involved (Stedefeldt et al., 2015). Educational actions may support the identification of the food handlers' needs at the workplace and include the establishment of workable goals with the involvement of the supervisor/manager (Da Cunha, Stedefeldt, \& De Rosso, 2014). Researchers suggested that they may enhance participants' motivations and improve the efficacy of the behavioural change (Arendt, Strohbehn, \& Jun 2015; Da Cunha, Stedefedlt, \& De Rosso, 2014). Nevertheless, research into the effectiveness of educational actions in a food service context is yet scarce.

Besides a proper training approach, it is crucial to find the training needs before designing the educational actions. A common method to discover these needs is the knowledge, attitude, and practices through a self-reported questionnaire for food handlers in combination with observations of actual practices (Zanin et al., 2017). However, in the context of educational actions, the needs are not only related to professional knowledge but also to personal skills and relationships. Therefore, some researchers recommended methods that can also assess cognitive and soft skills as these aspects also influence people's behaviour (Da Cunha, Braga, Passos, Stedefeldt, \& De Rosso, 2015; Yu et al., 2019). Another critical factor influencing the people behaviour is the organisations' food safety culture (FS-culture), which is much broader than the knowledge as it addresses the social context and experiences that shape the behaviour (Griffith, Livesey, \& Clayton, 2010a; Nyarugwe, Linnemann, Hofstede, Fogliano, \& Luning, 2016). Griffith, Livesey, and Clayton (2010b, p. 435) described the FS-culture as the aggregation of the prevailing, relatively constant, learned, shared attitudes, values, and beliefs contributing to the hygiene behaviours used within a particular food-handling environment. Da Cunha, Stedefeldt, and De Rosso (2014) hypothesised that the prevailing FS-culture may affect the effectiveness of educational actions since the FS-culture is determined by food handlers' norms, beliefs, and perceptions (Clayton \& Griffith, 2008). The assessment of the prevailing FS-culture may therefore, be a good starting point for defining the gaps as the basis for the development and implementation of educational actions.

However, the culture is not static but evolves (Griffith, Jackson, \& Lues, 2017), which requires the investigation of the impact of educational actions over time (Fujisaki, Shimpo, \& Akamatsu, 2019). To the best of our knowledge, no previous contribution performed a longitudinal study on the effects of educational actions on food handlers' behaviour and FS-culture in a food service context.

In part 1, Zanin, Luning, Da Cunha, and Stedefeldt (2021) described the mixed-method approach to collect, triangulate, and interpret data for assessing the prevailing FS-culture over time. This study (part 2) aimed to evaluate the effectiveness of educational actions in the transition of the FS-culture in a food service establishment in a longitudinal case study. The case studied is an army food service in Brazil and was selected because it suffers from persistent food safety challenges, as the correct time and temperature, the implementation of a sanitation plan and good handling practices in general. At the same time, the food service needs to continue serving food to people who need to stay in an excellent health condition.

\section{Materials and methods}

\subsection{Research approach and design}

The longitudinal study followed the principles of the participatory action research (Mertens, 2010) as this kind of action research can enhance the competencies of the researchers using feedback data in a cyclical process to increase the understanding of a given social situation (Hult \& Lennung, 1980, p. 247). Stakeholders from the Defense Ministry of Brazil as well as managers and food handlers of an army food service, collaborated in the study. The baseline assessment of the prevailing FS-culture, as previously described (Zanin et al., 2021, part 1), found the educational needs implemented during the longitudinal study. Monitoring the transition in the prevailing FS-culture occurred through assessment of FS-culture elements using the mixed-method approach, as previously described (Zanin et al., 2021, part 1).

Fig. 1 shows the longitudinal study design consisting of five periods. In the first four months, the prevailing FS-culture was assessed through participant observations, questionnaires, checklists, and microbiological analysis (Zanin et al., 2021, part 1). The baseline FS-culture assessment $(t=0)$ identified the educational needs and served as the basis for the development of educational actions. In the following nine months, the first author implemented the initial educational actions in the workplace. Afterwards, a re-assessment of the prevailing FS-culture was conducted during one month $(\mathrm{t}=1)$ to evaluate the educational actions. In the following six months, the managers received recommendations by the researcher to follow the same educational action scheme, i.e. the so-called refreshment educational actions. The last period encompassed the assessment of the prevailing FS-culture $(\mathrm{t}=2)$ and aimed at evaluating the sustainability of the educational actions (Fig. 1).

The first author performed, besides the first educational actions, all the three assessments of the prevailing FS-culture in the longitudinal research $(\mathrm{t}=0, \mathrm{t}=1$, and $\mathrm{t}=2$ ).

\subsection{Case study characterisation}

The food service establishment in an army headquarter of Brazil serves a large group of people (750 per day) throughout the whole week, which is a substantial number of individuals exposed to potential risks particularly in the case of a group that must remain in good health for adequate work performance. The food services in the Brazilian army have a characteristic workforce composition as all the food handlers are recruits and soldiers; most of them usually have neither experience nor education in food handling and hygiene. The food service establishment managers are part of the army force. Managers hold a higher military rank (such as sergeant or lieutenant) than that of the food handlers (soldiers) and usually have a permanent position. Managers have more experience in food service and administration practices but they do not necessarily have an educational background in food handling and hygiene. Moreover, there is a high turnover in food handlers; half of the individuals in the group changes each year.

The study assessed 59 food handlers and five managers, however, the number of food handlers varied at different times due to turnover. At $\mathrm{t}=$ 0,39 food handlers and three managers answered the questionnaires and participated in the initial educational actions. At $t=1$, the researchers assessed 29 food handlers ( 19 of which were the same as in $\mathrm{t}=$ 0 ). In the refreshment of the educational action and at $t=2,26$ food handlers (nine of which were the same as in $t=0$ and $t=1$ ) were assessed. The same three managers participated in $t=0$ and $t=1$, 


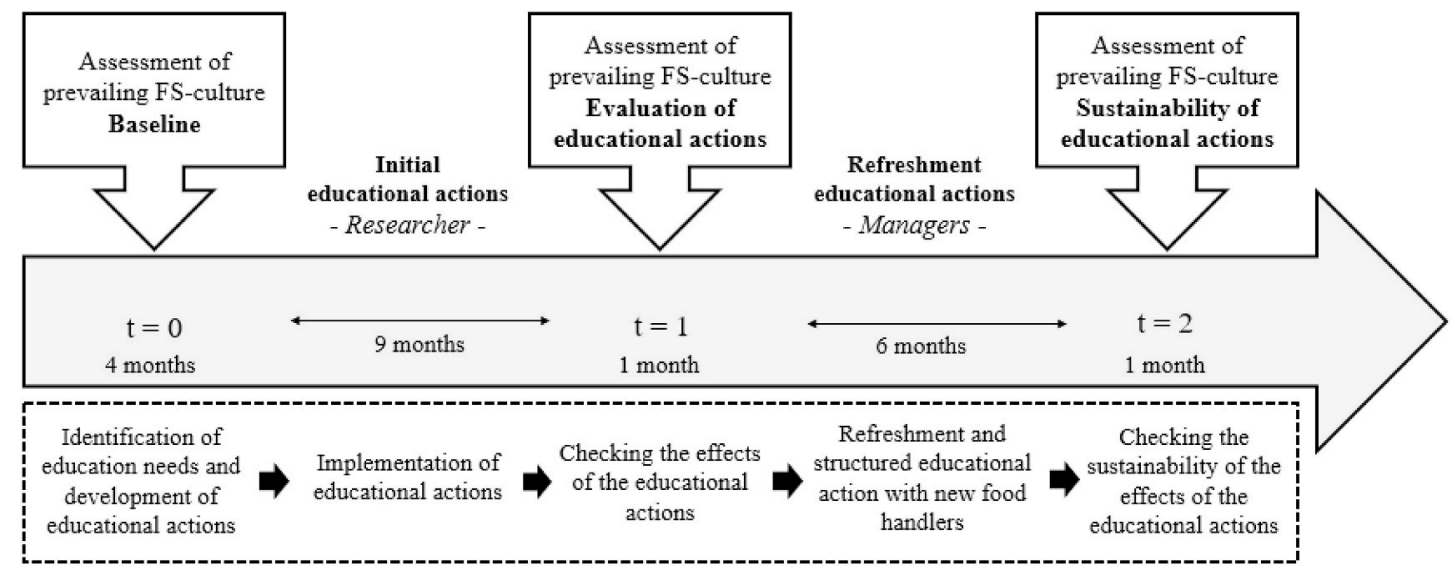

Fig. 1. Research design of the longitudinal study.

Notes: The biggest arrow shows the information about the FS-culture assessment and educational actions times in the longitudinal study.

The arrow boxes on the top indicate the moment that FS-culture was assessed.

The dotted box presents details about educational actions in the longitudinal study.

however, two of them changed between $t=1$ and $t=2$. The turnover was a limitation of this longitudinal study in food service.

More in detail, the food handlers were mostly men, and there was only one female manager. The managers presented different educational levels ranging from primary school to bachelor's degree, and most of the food handlers attended high school. In the baseline assessment $(t=0)$, $58 \%$ of the food handlers took part in food safety training or educational actions, which increased with the longitudinal study because of the interventions. In the last assessment, most food handlers took part (92\%) in the educational actions. Table 1 provides details of the characteristics of the participants.

\subsection{Assessment of FS-culture elements}

The prevailing FS-culture assessed eight elements including leadership, communication, knowledge, commitment, risk perception, work pressure and normative beliefs, work environment, and management systems, style, and process, as previously described (Zanin et al., 2021, part 1). The mixed-method approach consisted of a quantitative and a qualitative part. The quantitative data collection involved questionnaires for managers ( 32 items) and food handlers ( 52 items) to assess the
FS-culture elements. The leadership, communication, commitment, work pressure and normative beliefs, work environment and management systems, styles and process was assessed on a five-points Likert scale (Abidin, 2013). The knowledge was assessed by calculating the percentage of right answers (Da Cunha, Stedefeldt, \& De Rosso, 2014). Finally, the risk perception was judged on a scale ranging from extremely low risk $(-3)$ to extremely high risk $(+3)$ based on Raats, Sparks, Geekie, and Shepherd (1999). The checklist defined by Saccol, Hecktheuer, Richards, and Stangarlin (2006) was used to determine the percentage of compliance with work environment requirements. Another checklist assessed the food safety practices and the degree of risk of foodborne disease, as previously described by Da Cunha, Stedefeldt, and De Rosso (2014). The checklist consisted of thematic points, and the scoring system consisted of a five-risk levels (0.0, very low-risk; 0.1-13.2, low-risk; 13.3-502.6, average risk; 502.7-1152.2, high-risk; 1152.3-2565.95, very high-risk). In this system, a higher score represents a higher sanitary risk, and consequently, a higher risk of foodborne diseases. The microbiological analysis provided insights into the actual food safety risks. Participant observations using field notes were the input for the qualitative dataset. For details about the mixed-method approach, we refer the reader to Zanin et al. (2021, part 1).

Table 1

Characteristics of food handlers and managers.

\begin{tabular}{|c|c|c|c|c|c|c|}
\hline & \multicolumn{3}{|c|}{ Food handlers } & \multicolumn{3}{|c|}{ Managers } \\
\hline & $\mathbf{t}=\mathbf{0}$ & $t=1$ & $\mathbf{t}=\mathbf{2}$ & $\mathbf{t}=\mathbf{0}$ & $\mathbf{t}=\mathbf{1}$ & $t=2$ \\
\hline & $\mathrm{n}=39$ & $\mathrm{n}=29$ & $\mathrm{n}=26$ & $\mathrm{n}=3$ & $\mathrm{n}=3$ & $\mathrm{n}=3$ \\
\hline \multicolumn{7}{|l|}{ Gender } \\
\hline Male & $100 \%$ & $100 \%$ & $100 \%$ & $100 \%$ & $100 \%$ & $66.6 \%$ \\
\hline Female & $0 \%$ & $0 \%$ & $0 \%$ & $0 \%$ & $0 \%$ & $33.3 \%$ \\
\hline Age* $^{*}$ & $20.8(4.6)$ & $21.6(2.2)$ & $22.6(5.6)$ & $31.3(12.7)$ & $32.3(13.6)$ & $31.3(15.4)$ \\
\hline \multicolumn{7}{|l|}{ Education } \\
\hline Primary school & $28.2 \%$ & $24.1 \%$ & $19.2 \%$ & $33.3 \%$ & $33.3 \%$ & $33.3 \%$ \\
\hline High school & $71.8 \%$ & $69 \%$ & $80.8 \%$ & $33.3 \%$ & $33.3 \%$ & $66.6 \%$ \\
\hline Bachelor's degree & $0 \%$ & $6.9 \%$ & $0 \%$ & $33.3 \%$ & $33.3 \%$ & $0 \%$ \\
\hline $\begin{array}{l}\text { Participation in } \\
\text { Training/ } \\
\text { educational actions }\end{array}$ & $58 \%$ & $86 \%$ & $92 \%$ & $100 \%$ & $100 \%$ & $100 \%$ \\
\hline
\end{tabular}

Note: *Age expressed as mean (standard deviation). 


\subsubsection{Data analysis}

The mean value from the food handler's questionnaire (quantitative data) over time was assessed through analysis of variance with a fixed factor. The FS-culture elements (knowledge, commitment, risk perception, and work environment) which presented a p-value $<0.05$ were subjected to the Bonferroni's multiple comparison test. The analysis of the quantitative data was performed using R software (2011) and Microsoft Office Excel 365 ProPlus.

The optimistic bias was calculated using a paired Student's t-test and was considered optimistic when the mean value of the risk perception was negative and had a p-value $<0.05$ (Da Cunha, Stedefeldt, \& De Rosso, 2014).

The analysis of the qualitative data followed the thematic content analysis, according to Bardin (2016) with the MAXQDA software to support the data processing and visualisation (see Zanin et al., 2021, part 1 , for details).

\subsection{Educational actions}

The current study included two periods of educational actions. The initial educational actions, provided by the first author, were developed and implemented according to four phases: 1 ) identify and define the needs; 2) define workable objectives; 3) plan and implement a program/ action; 4) evaluate the process (based on Armstrong, 2014, p. 309; Luning \& Marcelis, 2020, p. 308). The actions developed based on the results of the baseline assessment of the prevailing FS-culture (phase one) were behavioural based. The objectives defined in phase 2 derived from the identified main nonconformities (i.e. those with a higher risk of foodborne diseases). The actions implemented in the workplace (phase three) aimed at translating the theoretical knowledge into work practices (Da Cunha et al., 2013; Rennie, 1994).

The refreshment actions followed a similar structure supported by the first author but executed by the food service managers. The managers were encouraged to develop confidence building through communication with the food handlers during the implementation of the educational action.

Table 2 shows the framework of the educational actions, including the needs inferred from the FS-culture baseline assessment results $(t=0)$ and contains details of each action. The actions were divided into tutored, planned, and educational actions with the managers; the last one was not conducted in the refreshment of educational actions. The development of the content of the educational actions was based on recommendations to achieve behavioural change, as previously described (Stedefeldt et al., 2015).

The tutored educational actions occurred in the course of the food service routines when the researcher noticed high-risk situations during the participant observations. When it occurred, the researcher corrected the routine into an adequate procedure in compliance with food safety requirements and hygiene regulations. The corrections were made using educational techniques based on the application of knowledge in the moment of the action (Stedefeldt et al., 2015). In some cases, the researcher demonstrated the adequate practice to the food handlers to learn together and in other cases, the food handlers performed adequate practices alone, after the feedback from the researcher.

The planned educational actions encompassed the themes: 1) food safety concepts through brainstorming; 2) implementation of environmental sanitation plans through practical activities; 3) understanding foodborne risk situations through local risk images; 4) learning the temperature monitoring through practical activities. Each planned action consisted of a plan with learning goals; program content, educational action methods, resources, and evaluation (see Supplementary materials A for details).

The educational action with the managers focused on knowledge about food safety through a messaging app, following the suggestion of Stedefeldt et al. (2015) about the use of interactive media. The actions included messages on a smartphone with necessary food safety

Table 2

Educational actions framework.

\begin{tabular}{|c|c|c|c|c|}
\hline FS-culture elements & Needs in the baseline assessment* & & Educational actions & Implementation \\
\hline Leadership & - Attribution of responsibilities. & Tutored** & Built the responsibility chart & Collective construction - managers and food handler. \\
\hline \multirow{3}{*}{$\begin{array}{l}\text { Communication and } \\
\text { knowledge }\end{array}$} & \multirow{2}{*}{$\begin{array}{l}\text { - Improve the knowledge in food safety of } \\
\text { food handlers and leaders. }\end{array}$} & Planned** & Food safety concepts & $\begin{array}{l}\text { Brainstorming and construction of concepts (food safety, } \\
\text { risk, hazards, and foodborne diseases). }\end{array}$ \\
\hline & & $\begin{array}{l}\text { With } \\
\text { managers }\end{array}$ & $\begin{array}{l}\text { Improvement of knowledge and } \\
\text { skills regarding food safety }\end{array}$ & $\begin{array}{l}\text { Updated materials in food safety and news about the } \\
\text { benefits of food safety in management. }\end{array}$ \\
\hline & $\begin{array}{l}\text { - Improve communication in an adequate } \\
\text { format. }\end{array}$ & Tutored** & $\begin{array}{l}\text { Creation of formal and informal } \\
\text { communication }\end{array}$ & $\begin{array}{l}\text { Support to the creation of suitable materials and the } \\
\text { managers during the daily communication. }\end{array}$ \\
\hline Commitment & $\begin{array}{l}\text { - Motivate the managers to improve their } \\
\text { commitment to food safety. }\end{array}$ & $\begin{array}{l}\text { With } \\
\text { managers }\end{array}$ & $\begin{array}{l}\text { Improvement of knowledge and } \\
\text { skills regarding food safety }\end{array}$ & $\begin{array}{l}\text { Updated materials in food safety and news about the } \\
\text { benefits of food safety in management. }\end{array}$ \\
\hline \multirow[b]{2}{*}{ Risk perception } & \multirow{2}{*}{$\begin{array}{l}\text { - Discuss the risk and hazard concepts. } \\
\text { - Awareness of high-risks situations in the } \\
\text { workplace. } \\
\text { - Increase the perception of lethality by } \\
\text { foodborne disease. }\end{array}$} & Planned** & Food safety concepts & $\begin{array}{l}\text { Brainstorming and construction of concepts (food safety, } \\
\text { risk, hazards, and foodborne diseases). }\end{array}$ \\
\hline & & Planned** & $\begin{array}{l}\text { Understanding foodborne risk } \\
\text { situations }\end{array}$ & $\begin{array}{l}\text { Group dynamics with local images of high-risks and } \\
\text { discussion of the potential hazards and risks involved. }\end{array}$ \\
\hline $\begin{array}{l}\text { Work pressure } \\
\text { and normative beliefs }\end{array}$ & $\begin{array}{l}\text { - Minimise the impact of hierarchy. } \\
\text { - Strengthen work cooperation. }\end{array}$ & Tutored** & $\begin{array}{l}\text { Integration of all levels of } \\
\text { hierarchy }\end{array}$ & $\begin{array}{l}\text { Development of a sense of responsibility and the } \\
\text { involvement of all levels of hierarchy in the same } \\
\text { discussion and activities. }\end{array}$ \\
\hline \multirow[t]{2}{*}{ Work environment } & $\begin{array}{l}\text { - Improve the infrastructure, equipment, } \\
\text { and utensils to perform safe practices. }\end{array}$ & $\begin{array}{l}\text { Planned** } \\
\text { Tutored** }\end{array}$ & $\begin{array}{l}\text { Implementation of environmental } \\
\text { sanitation plans } \\
\text { Delimitations of needs in the work } \\
\text { environment }\end{array}$ & $\begin{array}{l}\text { Responsibilities attribution and supervision activities to } \\
\text { put all the plan into action. } \\
\text { Constructions of the list of needs by the level of urgency. }\end{array}$ \\
\hline & $\begin{array}{l}\text { - Improve the workplace organisation } \\
\text { (Remove disused equipment). }\end{array}$ & Tutored** & Delimitation of equipment in disuse & Checklist with managers of the equipment in the kitchen. \\
\hline \multirow{5}{*}{$\begin{array}{l}\text { Management } \\
\text { systems, styles, and } \\
\text { process }\end{array}$} & \multirow{5}{*}{$\begin{array}{l}\text { - Decrease the degree of the risk. } \\
\text { - Implement time and temperature control. } \\
\text { - Adequacy of the required documents. } \\
\text { - Implement adequate defrosting. } \\
\text { - Avoid cross-contamination. } \\
\text { - Implement a sanitation plan. } \\
\text { - Results of microbiological analysis } \\
\text { according to Brazilian law limits. }\end{array}$} & Planned** & $\begin{array}{l}\text { Learning the temperature } \\
\text { monitoring }\end{array}$ & $\begin{array}{l}\text { Group dynamics to the correct monitoring of the } \\
\text { temperature. The dynamics included the measuring, } \\
\text { interpretation and spreadsheet completion. }\end{array}$ \\
\hline & & Tutored** & Defrosting process & Test of correct defrosting with food handlers. \\
\hline & & & Delimitation of the flow & Elaboration of the preparation flow in place. \\
\hline & & \multirow{2}{*}{ Planned** } & $\begin{array}{l}\text { Implementation of environmental } \\
\text { sanitation plans }\end{array}$ & $\begin{array}{l}\text { Collective construction of the sanitation plan (researcher, } \\
\text { managers, and food handlers). }\end{array}$ \\
\hline & & & $\begin{array}{l}\text { Learning the temperature } \\
\text { monitoring }\end{array}$ & Implementation of spreadsheets to the monitoring. \\
\hline
\end{tabular}

Notes: *Based on baseline assessment reported in Zanin et al. (2020, part. 1). **Educational actions followed by managers in the refreshment educational actions. Bold text shows the four planned educational actions 
information (such as microbial hazards, cross-contamination routes, hand washing practices, and foodborne diseases) in different formats: videos from the Brazilian government training program for food handlers (Health Ministry of Brazil, 2014), news on foodborne outbreaks, and legislation. After messages, the researcher and manager discussed what could be improved in the food service.

\subsubsection{Evaluation of educational actions}

The evaluation of educational actions (phase four) aimed to analyse the effectiveness of the actions and their impact on the prevailing FSculture. This evaluation consisted of a self-reported questionnaire and interviews.

The self-reported questionnaire included three open questions to evaluate the changes in food handler behaviour, the workplace after the educational actions, and what changes were still necessary (see Supplementary material B for details). All food handlers (29) and managers (3) from $t=1$ completed the questionnaire.

The second evaluation of educational actions, through interviews with food handlers (2) and managers (3), provided insight into the communication processes. The interview took place at a comfortable place with the researcher and the participant and consisted of seven questions related to the FS-culture elements (details are in Supplementary materials C). All participants agreed with the interview record, and the recordings were deleted after the transcription following the ethical approval.

\subsubsection{Data analysis of educational actions}

The analysis of qualitative data collected from the educational actions followed the thematic content analysis according to Bardin (2016) and detailed in Zanin et al. (2021, part 1). Categories were inferred using MAXQDA software support.

\subsection{Evaluation of triangulated scores to assess the FS-culture transition}

Data of the FS-culture assessments were triangulated using the scoring system as described in Zanin et al. (2021, part 1) to monitor the transition of the prevailing FS-culture in the longitudinal study (i.e. $\mathrm{t}=$ $0, \mathrm{t}=1$ and, $\mathrm{t}=2$ in Fig. 1 ).

\subsection{Ethical approval}

The Ethics Committee on Research of the Federal University of São Paulo approved the study (No. 2.040.338). All the participants agreed to participate and signed an informed consent.

\section{Results}

\subsection{Changes in the scores of the FS-culture elements}

Table 3 shows the changes in the scores of the FS-culture elements during the study as assessed through questionnaires for food handlers and managers. Four elements (knowledge, commitment, risk perception, and work environment) showed significant changes. The scores of the food handler's knowledge increased $(\mathrm{p}=0.007)$ from the baseline assessment at $\mathrm{t}=0(5.8, \mathrm{SD}=1.9)$ to the evaluation of educational actions at $\mathrm{t}=1(7.2,1.5)$. However, it did not present a significative difference after the assessment of the sustainability of educational actions at $\mathrm{t}=2(6.6,1.7)$. Likewise, the score for risk perception regarding food prepared by 'other food handlers in the same food service' increased ( $\mathrm{p}=0.037$ ) from $-2.0(1.0)$ to $-1.3(1.0)$ at $\mathrm{t}=0$ to $\mathrm{t}=1$, but it did not show a significant difference with $t=2$. The food handlers showed an optimistic bias regarding 'foods they made themselves' compared to 'foods prepared by other food handlers in another similar food service' at time 0 and 2 (p-values $=0.001$ and 0.022 , respectively). They were also optimistic regarding the 'food they made themselves' compared with foods prepared by 'another food handler in the same
Table 3

Scores of the FS-culture elements at the three times of assessment

\begin{tabular}{|c|c|c|c|c|}
\hline \multirow[t]{3}{*}{ Elements } & $\mathrm{t}=0$ & $\mathrm{t}=1$ & $t=2$ & \multirow{3}{*}{$\begin{array}{l}\mathrm{p}- \\
\text { value }\end{array}$} \\
\hline & \multicolumn{3}{|c|}{ Food handlers $(\mathrm{n}=59)$} & \\
\hline & $\mathrm{n}=39$ & $\mathrm{n}=29$ & $\mathrm{n}=26$ & \\
\hline Communication* & $4.0(0.6)$ & $4.1(0.7)$ & $4.2(0.7)$ & 0.501 \\
\hline Knowledge $e^{* *}$ & $\begin{array}{l}5.8 \\
(1.9)^{\mathrm{a}}\end{array}$ & $\begin{array}{l}7.2 \\
(1.5)^{\mathrm{b}}\end{array}$ & $\begin{array}{l}6.6(1.7)^{\mathrm{a}}, \\
\mathrm{b}\end{array}$ & 0.007 \\
\hline \multicolumn{5}{|l|}{ Commitment* } \\
\hline Affective & $\begin{array}{l}3.6 \\
(0.8)^{\mathrm{a}}\end{array}$ & $\begin{array}{l}3.9 \\
(0.8)^{\mathrm{a}, \mathrm{b}}\end{array}$ & $4.1(0.8)^{\mathrm{b}}$ & 0.023 \\
\hline Normative & $2.9(1.1)$ & $3.2(1.1)$ & $3.2(1.1)$ & 0.484 \\
\hline Continuance & $2.8(1.2)$ & $3.1(1.3)$ & $3.2(1.2)$ & 0.457 \\
\hline Food safety & $4.7(0.3)$ & $4.7(0.5)$ & $4.8(0.3)$ & 0.783 \\
\hline \multicolumn{5}{|l|}{ Risk perception ${ }^{* * *}$} \\
\hline $\begin{array}{l}\text { Other food handler in } \\
\text { another food service }\end{array}$ & $\begin{array}{l}-1.6 \\
(1.2)\end{array}$ & $\begin{array}{l}-1.4 \\
(1.4)\end{array}$ & $\begin{array}{l}-1.5 \\
(1.4)\end{array}$ & 0.843 \\
\hline From own work & $\begin{array}{l}-2.3 \\
(1.0)\end{array}$ & $\begin{array}{l}-1.9 \\
(1.2)\end{array}$ & $\begin{array}{l}-2.0 \\
(1.4)\end{array}$ & 0.365 \\
\hline $\begin{array}{l}\text { Other food handler in the } \\
\text { same food service }\end{array}$ & $\begin{array}{l}-2.0 \\
(1.0)^{\mathrm{a}}\end{array}$ & $\begin{array}{l}-1.3 \\
(1.0)^{\mathrm{b}}\end{array}$ & $\begin{array}{l}-1.6 \\
(1.4)^{\mathrm{a}, \mathrm{b}}\end{array}$ & 0.037 \\
\hline Lethality & $1.1(2.0)$ & $1.3(2.0)$ & $1.3(1.5)$ & 0.925 \\
\hline $\begin{array}{l}\text { Work pressure* and normative } \\
\text { beliefs* }\end{array}$ & $4.4(0.4)$ & $4.4(0.5)$ & $4.4(0.5)$ & 0.802 \\
\hline Work environment* & $\begin{array}{l}3.2 \\
(1.2)^{\mathrm{a}}\end{array}$ & $\begin{array}{l}2.8 \\
(0.8)^{\mathrm{a}}\end{array}$ & $3.9(0.9)^{\mathrm{b}}$ & 0.001 \\
\hline Leadership* & $4.0(0.9)$ & $4.1(0.7)$ & $4.4(0.6)$ & 0.121 \\
\hline \multirow[t]{3}{*}{ Management styles* } & $3.8(0.5)$ & $3.7(0.6)$ & $3.8(0.7)$ & 0.554 \\
\hline & \multicolumn{4}{|c|}{ Managers $(n=5)$} \\
\hline & $\mathbf{n}=\mathbf{3}$ & $\mathbf{n}=\mathbf{3}$ & $\mathbf{n}=\mathbf{3}$ & $\dagger$ \\
\hline Knowledge ${ }^{* *}$ & $5.0(0.0)$ & $8.0(1.0)$ & $7.7(1.1)$ & - \\
\hline \multicolumn{5}{|l|}{ Commitment* } \\
\hline Affective & $3.8(0.5)$ & $3.8(0.5)$ & $4.7(0.4)$ & - \\
\hline Normative & $2.9(1.0)$ & $3.8(1.4)$ & $3.9(0.9)$ & - \\
\hline Continuance & $2.9(0.9)$ & $4.0(1.0)$ & $3.6(0.5)$ & - \\
\hline \multicolumn{5}{|l|}{ Risk perception ${ }^{* * *}$} \\
\hline Another food service & $\begin{array}{l}-2.3 \\
(1.1)\end{array}$ & $\begin{array}{l}-1.0 \\
(2.6)\end{array}$ & $\begin{array}{l}-1.6 \\
(1.5)\end{array}$ & - \\
\hline Own food service & $\begin{array}{l}-1.3 \\
(1.5)\end{array}$ & $\begin{array}{l}-1.0 \\
(2.5)\end{array}$ & $\begin{array}{l}-2.0 \\
(1.0)\end{array}$ & - \\
\hline Lethality & $1.3(2.9)$ & $2.3(1.1)$ & $0.0(2.6)$ & - \\
\hline Management styles * & $4.3(0.2)$ & $4.7(0.5)$ & $4.8(0.3)$ & - \\
\hline
\end{tabular}

Notes: $\mathrm{t}=0$ : baseline; $\mathrm{t}=1$ : evaluation of educational actions; $\mathrm{t}=2$ : sustainability of educational actions. Values presented as mean (standard deviation).

* Elements assessed by five-points Likert scale - higher scores shows a tendency of food handlers and manager to agree with statements (Abidin, 2013).

** Element assessed by score 1 to 10 - scores $\geq 7.0$ show sufficient knowledge in food safety (Da Cunha, Stedefeldt, \& De Rosso, 2014).

$* * *$ Element assessed by scale -3 to +3 - higher scores show high-risk perception (De Andrade, Rodrigues, Antongiovanni, \& Da Cunha, 2019; Raats et al., 1999). P-value from the analysis of variance. Different letters show significative differences $(\mathrm{p}<0.05)$ by multiple comparisons of Bonferroni. Bold text shows p-value $<0.05$.

$\dagger$ Statistic is not available due to the sample size.

food service' after the educational actions at $\mathrm{t}=1$ and $\mathrm{t}=2$ ( $\mathrm{p}$-values $=$ 0.009 and 0.03 , respectively; see Supplementary materials D for further detailed results). The score for the affective commitment increased ( $\mathrm{p}=$ $0.023)$ between $t=0(3.6,0.8)$ and $t=2(4.1,0.7)$. Similarly, the score for enabling work environment increased $(\mathrm{p}=0.001)$ from the evaluation of educational actions $(\mathrm{t}=1 ; 2.8,0.8)$ to the sustainability of educational actions $(t=2 ; 3.9,0.9)$ (Table 3 ). Managers' scores for knowledge and continuance and normative commitment increased, but due to the small sample size, we could not test the differences in significance (Table 3).

Table 4 depicts the degree of compliance (expressed as \%) with facility requirements and the degree of sanitary risk of foodborne diseases. It shows an increase from $38.2 \%$ to $80.4 \%$ of compliance and a decrease from 'very high-risk' (1195.03) to 'average risk' (380.27) of foodborne diseases. The percentual of compliance increased between $t=0$ to $t=2$ 
Table 4

Degree of risk and facilities compliance (i.e. work environment) at three times of assessment.

\begin{tabular}{clll}
\hline & $\mathrm{t}=0$ & $\mathrm{t}=1$ & $\mathrm{t}=2$ \\
Degree of risk & 1195.03 & 922.75 & 380.27 \\
$\quad$ Classification & Very high-risk & High risk & Average risk \\
Facilities & $38.2 \%$ & $61.6 \%$ & $80.4 \%$ \\
compliance & Poor conditions to & Sufficient conditions & Adequate \\
Classification & perform safe & (need improvements) & conditions to \\
& practices & & perform safe \\
& & & practices \\
\hline
\end{tabular}

Notes: $\mathrm{t}=0$ : baseline; $\mathrm{t}=1$ : evaluation of educational actions; $\mathrm{t}=2$ : sustainability of educational actions.

The degree of risk ranged from 0 (very low-risk) to 2565.95 (very high-risk) (Da Cunha, De Oliveira, et al., 2014).

The facilities compliance follows the classification: $<50 \%$ : poor, $51-75 \%$ : sufficient (need improvements), and $>76 \%$ : adequate to perform safe practices (Saccol et al., 2006).

because of the adjustments in the facilities and the degree of risk changed due to improvements in practices, such as defrosting of foods, environment sanitation, hygiene of the food, and time and temperature control. These findings are consistent with the tendency of food handlers to agree that the work environment was enabling good practices (i.e. higher scores in the work environment in $\mathrm{t}=2$ ) as shown in Table 3.

\subsection{Improvement in routine activities over time}

Fig. 2 shows the categories that emerged from the participant observations during routine activities in the workplace during the longitudinal study. Data from the baseline assessment $(t=0)$, the evaluation of education actions $(t=1)$, and the evaluation of the sustainability of educational actions $(t=2)$, which resulted in respectively 4 , 4 , and 3 category themes, elicited improvements suggesting a transition in the prevailing FS-culture from reactive to more proactive. Fig. 2 also shows category themes as an independent outcome of educational actions (categories in $\mathrm{t}=0$ and concerning military rules in $\mathrm{t}=1$ ), as a primary outcome (which were closely related to actions performed), and as a secondary outcome (which were dependent on administrative issues).

Three of the four categories that emerged from the baseline assessment reflected poor safety practices, which are associated with a more reactive FS-culture. For example, the category 'sanitation circumstances and practices' covers procedures, products, and frequency of hygiene that did not comply with rules and law requirements. The category 'behaviours toward food safety' refers to inadequate behaviours for food safety and negative aspects of the military hierarchy, which influenced the manager's behaviours. Interestingly, the category 'collective improvement actions' showed that there was motivation to change behaviours, which is more typical for an active FS-culture (Fig. 2).

The evaluation of educational actions $(t=1)$ elicited two categories reflecting more reactive FS-culture situations and two situations typical for an active FS-culture (Fig. 2). The category 'high-risk situations and management system' encompassed unsuitable work environment, crosscontamination, improper monitoring of time and temperature, and inefficient management systems, which typically reflects a reactive FSculture situation. The category 'beyond the educational actions' showed some aspects characteristic for an active FS-culture such as the implementation of a hygiene plan, improvements in facilities and equipment, innovative ideas to improve the management system, and the commitment of managers to perform it.

The categories that emerged from the evaluation of the sustainability of educational actions $(t=2)$ revealed aspects indicative of a more proactive FS-culture such as improved administrative actions, work environment and routines, and behaviours. For example, the category 'positive changes in the work environment' reflects the restructuration of the place, the new facilities, and the organisation in the kitchen. Some of these changes were dependent on administrative issues but changed

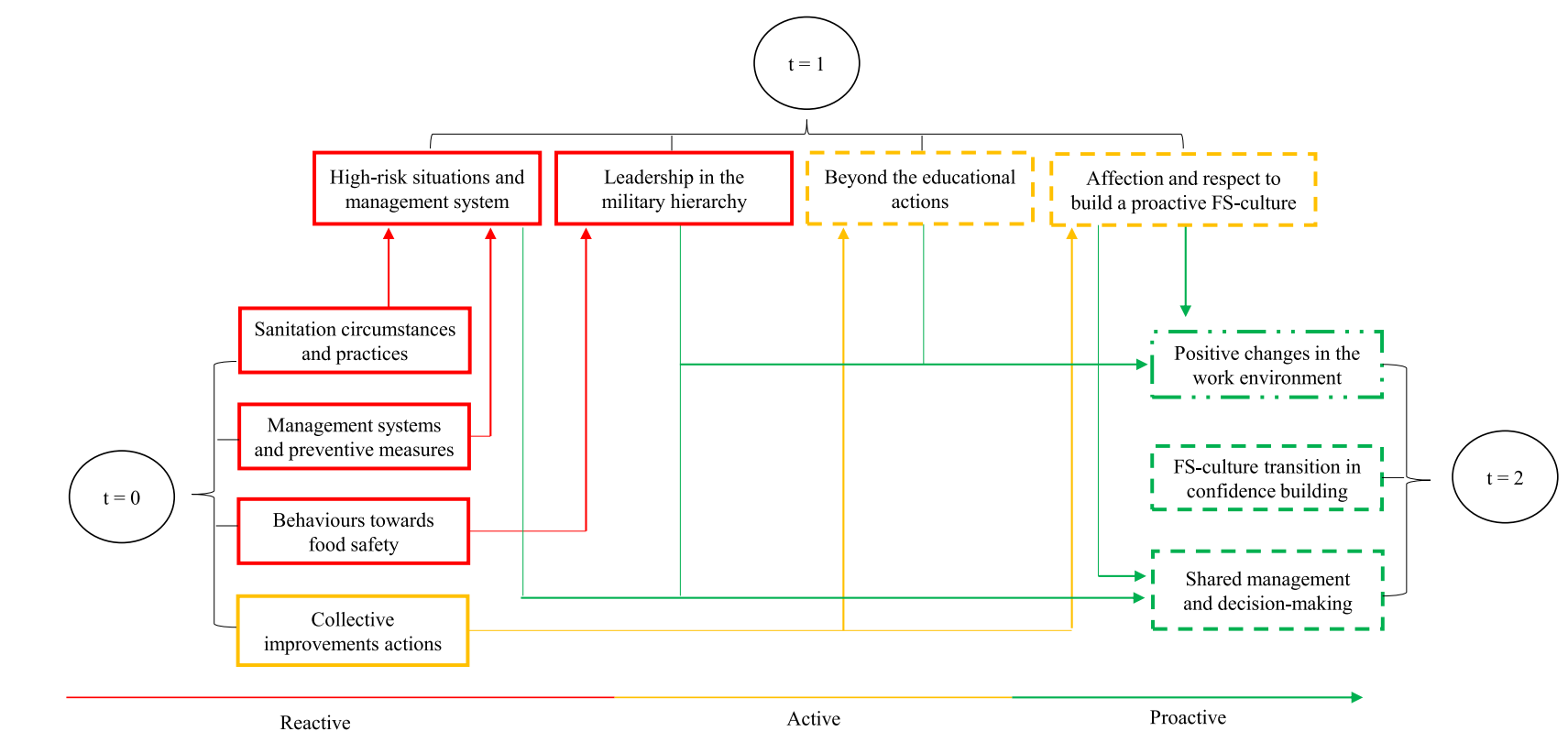

- Outcome independent of educational actions

- - - - - Primary outcome of educational actions

— - . - . - S S S condary outcome of educational actions

Fig. 2. Categories from the participant observation at three times of assessment.

Source: Adapted from Arendt et al. (2014).

Notes: $\mathrm{t}=0$ : baseline; $\mathrm{t}=1$ : evaluation of educational actions; $\mathrm{t}=2$ : sustainability of educational actions.

FS $=$ food safety.

Differences in line of the boxes show the type of outcome concerning educational actions.

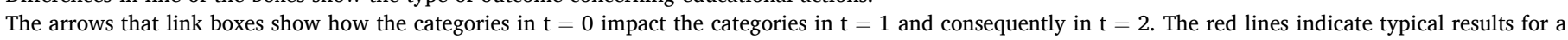

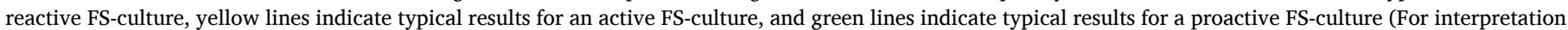
of the references to colour in this figure legend, the reader is referred to the web version of this article). 
because of the managers' behaviours. These changes are secondary outcomes of the educational actions (see Fig. 2). The second category 'FS-culture transition in confidence-building' showed a great representation of changes in the mandatory food safety behaviours in the daily routine as well as changes in the human relations in the group (Fig. 2). The human relations were more based on confidence building, so that food handlers did not feel afraid to communicate about food safety and hygiene issues. The last category 'shared management and decision- making' suggested changes in the way of working in the workplace because managers and food handlers were involved in the management process during the implementation of improvements. Also, managers analysed the priorities to make improvements based on the food handlers' routine and communication, which demonstrated a more proactive situation.

Table 5

Triangulated data at three times of assessments.

\begin{tabular}{|c|c|c|c|c|c|c|c|c|}
\hline \multirow[t]{2}{*}{ FS-culture elements } & \multirow{2}{*}{$\begin{array}{l}\text { Educational } \\
\text { actions } \\
\text { implemented }\end{array}$} & \multirow[t]{2}{*}{ Characteristics of elements } & \multicolumn{2}{|c|}{ Triangulation $-\mathrm{t}=0$} & \multicolumn{2}{|c|}{ Triangulation $-\mathrm{t}=1$} & \multicolumn{2}{|c|}{ Triangulation $-\mathrm{t}=2$} \\
\hline & & & $\begin{array}{l}\text { Characteristic } \\
\text { score }\end{array}$ & $\begin{array}{l}\text { Score } \\
\text { a }\end{array}$ & $\begin{array}{l}\text { Characteristic } \\
\text { score }\end{array}$ & $\begin{array}{l}\text { Score } \\
\text { a }\end{array}$ & $\begin{array}{l}\text { Characteristic } \\
\text { score }\end{array}$ & $\begin{array}{l}\text { Score } \\
\text { a }\end{array}$ \\
\hline \multirow[t]{4}{*}{ Leadership } & $\begin{array}{l}\text { - Tutored } \\
\text { - With the } \\
\text { manager }\end{array}$ & $\begin{array}{l}\text { Managers influencing food handlers in safe } \\
\text { practices and not providing vision, } \\
\text { assistance, or guidance. }\end{array}$ & $1+2$ & 1 & $1+2$ & 2 & $3+3$ & 3 \\
\hline & & Praising and recognition. & 1 & & 2 & & 3 & \\
\hline & & $\begin{array}{l}\text { Visible and credible leadership commitment } \\
\text { to FS and accountability. }\end{array}$ & 1 & & 2 & & 3 & \\
\hline & & $\begin{array}{l}\text { Company's policies, systems, and processes } \\
\text { incentivising FS decisions at every level of } \\
\text { the organisation. }\end{array}$ & 1 & & 2 & & 3 & \\
\hline \multirow[t]{4}{*}{ Communication } & - Tutored & Necessary information and instructions. & 2 & $1-2$ & $3+3$ & 3 & $3+3$ & 3 \\
\hline & & $\begin{array}{l}\text { Freedom and motivation of communication } \\
\text { between managers and food handlers } \\
\text { aiming at improving safe practices. }\end{array}$ & $1+2$ & & 2 & & $3+3$ & \\
\hline & & $\begin{array}{l}\text { Visible demonstrations through } \\
\text { communication that food safety is } \\
\text { important. }\end{array}$ & 1 & & 3 & & 3 & \\
\hline & & Communications related to food safety. & 2 & & 3 & & 3 & \\
\hline \multirow[t]{2}{*}{ Knowledge } & $\begin{array}{l}\text { - Planned action } \\
\text { - With the }\end{array}$ & $\begin{array}{l}\text { Level of knowledge for most food safety } \\
\text { issues. }\end{array}$ & $1+2$ & $1-2$ & $2+3$ & $2-3$ & $2+2$ & $2-3$ \\
\hline & manager & $\begin{array}{l}\text { Explaining the reason for each food safety } \\
\text { requirements. }\end{array}$ & 1 & & 3 & & 3 & \\
\hline \multirow[t]{3}{*}{ Commitment $^{\mathrm{b}}$} & - & $\begin{array}{l}\text { Alignment of values and beliefs between } \\
\text { employees and organisation for safe food } \\
\text { handling practices. }\end{array}$ & $2+3$ & $2-3$ & $3+3$ & 3 & $3+3$ & 3 \\
\hline & & $\begin{array}{l}\text { Commitment to food safety: consideration } \\
\text { of adequate practices as a priority and } \\
\text { feeling of responsibility to follow } \\
\text { established standards. }\end{array}$ & $2+3$ & & $3+3$ & & $3+3$ & \\
\hline & & Manager commitment. & 2 & & 2 & & 3 & \\
\hline \multirow[t]{4}{*}{ Risk perception } & - Planned action & Risk perception of situations of high-risk. & $1+1$ & 1 & $2+3$ & 3 & $2+3$ & 2 \\
\hline & & $\begin{array}{l}\text { Recognition of the term "risk" and "hazard" } \\
\text { and their meanings. }\end{array}$ & 1 & & 3 & & 3 & \\
\hline & & $\begin{array}{l}\text { Perception of lethality risk of foodborne } \\
\text { diseases. }\end{array}$ & 2 & & $3+3$ & & 2 & \\
\hline & & $\begin{array}{l}\text { Optimistic/pessimistic bias about co- } \\
\text { workers and/or places like theirs. }\end{array}$ & 1 & & 3 & & 1 & \\
\hline \multirow[t]{2}{*}{$\begin{array}{l}\text { Work pressure and } \\
\text { normative beliefs }\end{array}$} & - Tutored & $\begin{array}{l}\text { Workload, time to perform activities, and } \\
\text { amount of food handler affecting the } \\
\text { practice of FS. }\end{array}$ & $1+3$ & 2 & $2+3$ & $2-3$ & $3+3$ & 3 \\
\hline & & $\begin{array}{l}\text { Pressure from bosses, colleagues, health } \\
\text { authorities, or consumers. }\end{array}$ & $1+3$ & & $2+3$ & & $3+3$ & \\
\hline \multirow[t]{4}{*}{ Work environment } & $\begin{array}{l}\text { - Planned action } \\
\text { - Tutored }\end{array}$ & $\begin{array}{l}\text { Adequate environment and enough } \\
\text { resources (infrastructure, utensils, } \\
\text { equipment, hygiene products) to perform } \\
\text { safe practices. }\end{array}$ & $1+2$ & $1-2$ & $1+2$ & 2 & $2+3$ & 3 \\
\hline & & Environment adequacy assessment. & 1 & & 2 & & 3 & \\
\hline & & Environment adequacy performance. & 1 & & 2 & & 3 & \\
\hline & & Efforts to improve infrastructure adequacy. & 2 & & 3 & & 3 & \\
\hline \multirow[t]{4}{*}{$\begin{array}{l}\text { Management } \\
\text { systems, styles, and } \\
\text { process }\end{array}$} & $\begin{array}{l}\text { - Planned action } \\
\text { - Tutored }\end{array}$ & $\begin{array}{l}\text { Involvement of managers in motivation and } \\
\text { team building to implement safe practices } \\
\text { and quality tools. }\end{array}$ & $1+2$ & 1 & $1+2$ & $1-2$ & $3+3$ & $2-3$ \\
\hline & & $\begin{array}{l}\text { Documented procedures and record forms } \\
\text { to support food safety. }\end{array}$ & 1 & & 2 & & 3 & \\
\hline & & $\begin{array}{l}\text { Prerequisite programs, HACCP, or some } \\
\text { system based on good hygiene practices. }\end{array}$ & 1 & & 2 & & 2 & \\
\hline & & Management process. & $1+1$ & & $1+1$ & & $2+2$ & \\
\hline Total & & & & $1-2^{c}$ & & $2-3^{c}$ & & $2-3^{c}$ \\
\hline
\end{tabular}

Notes: $\mathrm{t}=0$ : baseline; $\mathrm{t}=1$ : evaluation of educational actions; $\mathrm{t}=2$ : sustainability of educational actions.

a FS-culture score system: 1 - reactive; $1-2$ - reactive to active; 2 - active; $2-3$ - active to proactive; 3 - proactive.

b Element used as propelling to change other elements and the FS-culture.

c Characterisation of FS-culture. 


\subsection{Effectiveness of the educational action process}

The evaluation of the educational action process by the food handlers using the questionnaires resulted in two categories: 'changes in attitudes and practices after educational actions' and 'challenges and possibilities in the transition of FS-culture'. These categories showed that the food handlers perceived changes in their attitudes and practices after the educational actions, as demonstrated by response 1 . The food handlers also perceived other possibilities to improve the degree of risk of foodborne diseases, as illustrated by response 2 .

'It is notable the change in the environment and in us, food handlers. Previously we saw something wrong and left it wrong, nowadays we correct each other and try to improve with it' (response 1).

'It is necessary to let everyone be aware of our potential to minimise the risks and to identify the critical situation, for example, the defrosting meat at room temperature' (response 2).

The evaluation of the educational action process assessed through interviews with the food handlers and managers resulted in three categories: 'negative aspects for food safety', 'indicators to work dedication' and 'FS-culture transition reflected in personal relationships'. The first two categories demonstrated that some characteristics of the public administration and military hierarchy, as bureaucracy, were not within reach of the educational actions and affected food safety negatively. However, the results also showed changes in personal relationships and team interaction after educational actions. The response of interviewee 1 showed the robust military characteristics at the beginning of the research. After the educational action, the interviewee demonstrated empathy for the food handlers and understood his responsibilities to achieve a proactive FS-culture while maintaining the military hierarchy.

'Now, I see myself as a person who can change and who has the responsibility to manage time and people. It is also my responsibility to improve the quality and to take care of the management of food safety' (interviewee 1).

\subsection{Transition of the prevailing FS-culture}

Table 5 shows the transition of the prevailing FS-culture over time based on the triangulated data collected for the FS-elements and using the interpretation grid (Zanin et al., 2021, part 1). It shows that the prevailing FS-culture changed from 'reactive-active' (assigned score $1-2)$ in the baseline assessment $(t=0)$ to 'active-proactive' $(2-3)$ in the evaluation $(t=1)$ and the sustainability of the educational actions $(t=$ 2 ). This suggests that the educational actions were effective in changing the initial prevailing FS-culture into a more proactive FS-culture. The educational actions also sustained after managers actions, although some differences in scores of the FS-culture elements between $t=1$ and $\mathrm{t}=2$ were present.

The element 'leadership', for example, scored at $\mathrm{t}=0, \mathrm{t}=1$, and $\mathrm{t}=$
2, 1 (reactive), 2 (active), and 3 (proactive), respectively (Table 5). Scores of other elements such as work pressure, normative beliefs, and management systems, styles, and process only increased between $t=1$ and $\mathrm{t}=2$. In contrast, some elements did not change between $\mathrm{t}=1$ and $\mathrm{t}$ $=2$, such as communication, knowledge, and commitment. Only the score for risk perception decreased from 3 (proactive) at $\mathrm{t}=1$ to 2 (active) at $\mathrm{t}=2$.

Table 6 shows the microbiological performance during the longitudinal study. At the baseline assessment, most parameters complied with the maximum value allowed by the Brazilian law, except for Bacillus cereus in the meat sample, which suggests a risk of foodborne disease. However, parameters remained within the legal limits over time as well at $\mathrm{t}=1$ and $\mathrm{t}=2$. It appears that as the FS-culture changed to a more proactive direction, the microbiological performance also improved. The microbiological performance is not an element of the FS-culture but indicates a snapshot evaluation. Therefore, it may under or overestimate the food safety performance.

\section{Discussion}

\subsection{Effectiveness of educational actions in changing prevailing FS-culture}

The educational actions changed the prevailing FS-culture from reactive to more proactive from the baseline assessment $(t=0)$ to evaluating the sustainability of the actions $(t=2)$ (Table 5$)$. The proactive FS-culture remained six months later $(t=2)$ after the local manager performed the refreshments of the educational actions. The refreshment of the educational actions plays an essential role in changing behaviour and retention of skills (McFarland et al., 2019). The educational actions in the current study were behaviour-based as proposed by other studies (McFarland et al., 2019; Yu et al., 2018).

The results indicated that not all the elements of the FS-culture seem to be influenceable by educational actions. For example, changing the work environment requires investments and financial support; intersectoral actions and other improvements require relationships with stakeholders and consumers (Arendt et al., 2015), which are not primary outcomes of the educational actions for food handlers and managers. The prevailing FS-culture differs for each food services/companies as it depends on the supportiveness of the existing technological infrastructure and organisational/administrative conditions that may enable or constrain the execution of food safety and hygiene tasks (Luning \& Marcelis, 2020; Nyarugwe, Linnemann, \& Luning, 2020). Thus, the impact of the educational actions can differ depending on the character of the prevailing FS-culture as shaped by the existing technological and organisational conditions.

The educational actions in the longitudinal study also revealed an interesting phenomenon in risk perception, i.e. the optimistic bias. In the baseline assessment $(t=0)$, the risk perception of foodborne diseases was classified as 'low risk' (Table 3), although the degree of risk in the food service was classified as 'very high-risk' (Table 4). This means that the food handlers prepared and processed food in a 'very high-risk'

Table 6

Microbiological performance over time.

\begin{tabular}{|c|c|c|c|c|c|}
\hline Sample & Parameters & $\mathrm{t}=0$ & $\mathrm{t}=1$ & $\mathrm{t}=2$ & MVA $^{\mathrm{a}}$ \\
\hline \multirow[t]{5}{*}{ Meat (processed) } & Coagulase positive Staphylococci & $<1.0 \times 10^{2}$ & $<1.0 \times 10^{2}$ & $<1.0 \times 10^{2}$ & $10^{3} \mathrm{CFU} / \mathrm{g}$ \\
\hline & Coliforms at $45^{\circ} \mathrm{C}$ & $<3$ & $<3$ & 11 & $2.0 \times 10^{1} \mathrm{MPN} / \mathrm{g}$ \\
\hline & Bacillus cereus & $1.6 \times 10^{3}$ & $<1.0 \times 10^{2}$ & $<1.0 \times 10^{2}$ & $10^{3} \mathrm{CFU} / \mathrm{g}$ \\
\hline & Salmonella spp. & Absent & Absent & Absent & Absent in $25 \mathrm{~g}$ \\
\hline & Clostridium at $46^{\circ} \mathrm{C}$ & $<1.0 \times 10^{1}$ & $<1.0 \times 10^{1}$ & $<1.0 \times 10^{2}$ & $10^{3} \mathrm{CFU} / \mathrm{g}$ \\
\hline \multirow[t]{2}{*}{ Salad (raw) } & Coliforms at $45{ }^{\circ} \mathrm{C}$ & $<3$ & $<3$ & $<3$ & $10^{2} \mathrm{MPN} / \mathrm{g}$ \\
\hline & Salmonella spp. & Absent & Absent & Absent & Absent in $25 \mathrm{~g}$ \\
\hline
\end{tabular}

Notes: $\mathrm{t}=0$ : baseline; $\mathrm{t}=1$ : evaluation of educational actions; $\mathrm{t}=2$ : sustainability of educational actions.

CFU: colony forming units. MPN: most probable number.

Value in bold: non-conformity.

a Maximum value allowed, according to Health Ministry of Brazil (2019). 
situation, but they did not realise it. After the initial educational actions, food handlers' and managers' awareness of concepts regarding food safety, foodborne diseases, hazards, and risks increased as they were informed about the very high-risk observed in the baseline assessment. This may explain why the food handlers showed a lower score for 'risk perception' at $\mathrm{t}=0$ (Table 3). During the refreshment educational actions, the local manager informed the food handlers that the degree of risk was lower, whereas the compliance with the work environment requirements was high and adequate to perform safe practices. Moreover, the food handlers observed improvements in the work environment (such as the renovation of kitchen structure, new utensils, and equipment), and they were actively involved in changing the workplace. These actions implemented during the longitudinal study resulted in a decrease in risk perception between $\mathrm{t}=1$ and $\mathrm{t}=2$ (Table 3 ).

Several reasons may explain the observed changes. From our findings, we assumed that food handlers' changes in their risk perception might be caused by improvements in the workplace.De Andrade etal, 2020 Stedefeldt, Zanin, and Da Cunha (2021) described the risk perception as an independent variable and argued that a complacent feeling or self-satisfaction about the environment might overestimate practices and lower risk perceptions as well. In another transversal study, the researchers stated that a low-risk perception might indicate that food handlers neglect adequate practices (De Andrade et al., 2019). However, in our longitudinal study we also observed that the various changes in the degree of risk might have favoured the low-risk perception in $t=2$. Thus, interpretation of risk perception needs to be done carefully because these continuous changes can lead to food handlers judging the risk based on the information that the risk has changed.

The optimistic bias revealed another unexpected change in the longitudinal study. At $\mathrm{t}=0$, the food handlers showed an optimistic bias concerning 'other food handlers in another food service', at $t=1$ they changed the optimistic bias concerning 'another food handler in the same food service', and at $t=2$ they showed an optimistic bias for both situations (Supplementary material D). Although some researchers pointed out that a food handler with optimistic bias tends to neglect adequate behaviours more frequently (Da Cunha et al., 2015), the effect of optimistic bias on practices seems to be not one-sided (Da Cunha, De Rosso, Pereira, \& Stedefeldt, 2019). In the current study, educational actions and risk communication might have affected the optimistic bias. In addition, the high-risk perception of lethality can strengthen their optimistic bias, as they see their peers as more vulnerable than themselves (Da Cunha et al., 2015).

A substantial improvement in the degree of risk was attained, although it did not reach the best score (i.e. very low risk) (Table 4). Possibly, it may require continuous encouragement of educational actions to achieve the best results in the long run (Stedefeldt et al., 2015; Arendt et al., 2015). Moreover, the percentage of compliance with the facility requirements increased from $38.2 \%$ at $\mathrm{t}=0-80.4 \%$ at $\mathrm{t}=2$, demonstrating that the educational actions changed the poor conditions into adequate conditions to perform safe practices (Table 4). This compliance shows, in fact, a basic legal requirement (Defense Ministry of Brazil, 2015; Health Ministry of Brazil, 2004). Stedefeldt et al. (2015) discussed that the enable environment resources is a key factor to the success of educational actions, because without an adequate work environment is not possible to motivate food handlers to desirable behaviours.

Our qualitative results suggested that changes in the administrative actions in the food service were another influencer of the prevailing FSculture (Fig. 2). The public administration system was highlighted in interviews as a negative aspect influencing the effectiveness of the educational actions as illustrated by interviewee 1 .

'... The hardest part of my job is thinking about how to make it work here (food service), following all the food safety criteria, without going over the bureaucracy of public administration ...' (Interviewee 1$)$.
The public administration conditions can be an obstacle for the food service as they may affect the management systems because financial support and intersectoral actions are necessary to implement improvements in the systems. According to the GFSI position paper on FS-culture (2018), the administration and proper allocation of resources is an outcome of committed leadership. However, bureaucratic procedures in public administration may hamper commitment. Usually, bureaucracy implies time-consuming procedure-driven actions and following strict authority lines (Luning \& Marcelis, 2020). During the participant observation, the researcher, managers, and commandant of the army headquarter articulated several times the noncompliance to the work environment requirements, which was improved by the investment in proper allocation of financial resources as seen in the field note below:

'The work environment was fully restructured. New facilities were provided, and the place was reorganised; for example, the old equipment had a destination and was not inside the workplace'.

\subsection{Usefulness of the FS-culture assessment as a starting point for educational actions}

Prevailing FS-culture is the phenomenon that can explain, among other things, the food business' context (organisational and technological conditions) and the relationships inside the workplace (personal characteristics) (Nyarugwe et al., 2016). The FS-culture assessment was an appropriate starting point to identify the needs for developing educational actions. In our study, the baseline assessment $(t=0)$ showed that the technological infrastructure, leadership, work environment, situations of high-risk of foodborne diseases, and noncompliance to hygiene procedures were the main requirements that needed improvements (Table 5). Additionally, the low-risk perception was a weakness of food handlers (Table 3). Therefore, educational actions also focused on creating awareness of various food safety-related concepts to strengthen their risk perception (Table 2).

The FS-culture assessment covers well the complexity of food services, which are characterised by a context with different suppliers, preparations involving different risks and a significant turnover of food handlers, among others things (Luning, Chinchilla, Jacxsens, Kirezieva, \& Rovira, 2013; Stedefeldt et al., 2017). Various researchers stressed that both the needs of food handlers and the workplace reality need to be identified, as each food service requires a specific strategy to change ( $\mathrm{Da}$ Cunha, Stedefeldt, \& De Rosso, 2014; Stedefeldt et al., 2015; Thaivalappil, Waddell, Greig, Meldrum, \& Young, 2018). According to Yu et al. (2018), a research-supported and behaviour-based education intervention, based on antecedents and consequences of employees' behaviours, can improve desired behaviours. In our study, after the educational actions planned by the researcher, managers were making decisions based on priorities decided in the FS-culture assessments, as illustrated in the field note bellow:

'The managers and the food handlers are involved in the improvements, trying to do what is needed to improve the environment based on the priorities'.

The planning of the educational action anchored in the results of multiple FS-culture elements, as performed in our study, may enhance the effectiveness of educational actions as previously discussed by Fujisaki et al. (2019) and change behaviours of food handlers as suggested by Yiannas (2015).

\subsection{Context of military conditions and methodological considerations}

During this longitudinal study, we experienced the specific characteristics of the army food service elicited in some typical military behaviour. This was a given fact and sometimes appeared to be an obstacle to change FS-culture but once the organisational culture of the 
institution became clear, this difficulty could be managed. The qualitative categories showed that the military hierarchy could have affected the FS-culture at $\mathrm{t}=0$ and $\mathrm{t}=1$ (Fig. 2). However, at $\mathrm{t}=2$ the category 'FS-culture transition in confidence-building' revealed that the confidence-building was manageable within the military hierarchy as exemplified in the field note below:

'The managers and the food handlers are feeling comfortable with the changes in the work environment and group behaviour. They seem to be happy with the new situation and are committed. Apparently, they do not feel afraid of the military hierarchy'.

Besides the hierarchy, the work pressure is an element that is common and cultivated in the military behaviour. This may have affected the workload and the food handlers' behaviour towards food safety (Yu et al., 2018). In contrast, the high level of affective commitment (Table 3) are also typical of the military context and might be useful as a motivator to adequate behaviours. Yu et al. (2018) demonstrated that motivation could influence the retention of acquired skills affecting behaviours and attained through educational actions. The military conditions reinforce the recommendation that it is necessary to know the organisational culture before, to investigate the FS-culture as stressed by Nyarugwe et al. (2016).

A methodological consideration of the study is that the researcher performed the first educational actions, whereas the local manager did the refreshment actions. This caused some differences in using the education techniques, which could have affected the results. The different food handlers and managers sampled at different times in the study and represented also a limitation of the longitudinal study. Nevertheless, the action research with participant observations facilitated the recognition of the researcher as part of the group and the creation of confidence between the researcher and the participants, which was indispensable to evolve the FS-culture. The confidence relation between managers and food handlers or between educational action instructors and food handlers is necessary to achieve improvements in food safety requirements, as previously stressed by Arendt et al. (2014) and Stedefeldt et al. (2015).

\section{Conclusions and recommendations}

This paper is the first published research that used FS-culture assessment as the basis for the development of educational actions and monitoring the transition in the prevailing FS-culture during a longitudinal study in a food service context. The educational actions based on educational needs, confidence building, and adequate methods for food handlers were effective in the transition of the FS-culture in this longitudinal case study. It was proved by the transition from a 'reactiveactive' FS-culture in the baseline assessment to an 'active-proactive' FSculture at $\mathrm{t}=1$, i.e. after the initial educational action, and by the sustained 'active-proactive' FS-culture after the local manager's actions. The mixed-methods approach and the interpretation grid of FS-culture assessment were useful for monitoring the transition in the prevailing FS-culture. Further investigations may use this approach to test its usefulness for other types of food services and in other countries, as this study was conducted in the context of a Brazilian army food service. We also recommend converting the scientific methods to FS-culture assessment into methods suitable for the use by food safety managers in food services.

\section{Funding and Acknowledgements}

This research was supported by Coordenação de Aperfeiçoamento de Pessoal de Nível Superior - Brasil, CAPES scholarship /PDSE - Process no $\{88881.190230 / 2018-01\}$ and by the Conselho Nacional de Desenvolvimento Científico e Tecnológico (Cnpq/Brazil) - Process $n^{\circ}\{403528 /$ 2016-0\}.This study was partly executed at Wageningen University in
The Netherlands.

The authors acknowledge the Defense Ministry of Brazil and the Brazilian Army for the partnership to this study. Also, acknowledge Eneo Alves da Silva Junior, who assisted the microbiological analysis, Fábio Tadeu Montesano, who supported statistical analysis, and Carlos Alberto de Oliveira Júnior, who reviewed the text.

\section{CRediT authorship contribution statement}

Laís Mariano Zanin: Conceptualization, Investigation, Methodology, Writing - original draft, Visualization. Elke Stedefeldt: Conceptualization, Methodology, Data curation, Supervision, Project administration. Sueli Maria da Silva: Data curation, Methodology, Formal analysis. Diogo Thimóteo da Cunha: Data curation, Methodology, Formal analysis. Pieternel A. Luning: Conceptualization, Supervision, Methodology, Writing - review \& editing.

\section{Declaration of interests}

The authors declare that they have no known competing financial interests or personal relationships that could have appeared to influence the work reported in this paper.

\section{Appendix A. Supplementary data}

Supplementary data to this article can be found online at https://doi. org/10.1016/j.foodcont.2020.107542.

\section{References}

Abidin, U. F. U. Z. (2013). Measuring food safety culture: Insights from onsite foodservice operations. Iowa State University.

Arendt, S. W., Roberts, K. R., Strohbehn, C., Arroyo, P. P., Ellis, J., \& Meyer, J. (2014). Motivating foodservice employees to follow safe food handling practices: Perspectives from a multigenerational workforce. Journal of Human Resources in Hospitality \& Tourism, 13(4), 323-349. https://doi.org/10.1080/ 15332845.2014.888505.

Arendt, S. W., Strohbehn, C., \& Jun, J. (2015). Motivators and barriers to safe food practices: Observation and interview. Food Protection Trends, 35(5), 365-376.

Armstrong, M. (2014). Armstrong's handbook of human resource management practice $\left(13^{\text {th }}\right.$ ed.). London: Kogan Page Ltd.

Bardin, L. (2016). Análise de Conteúdo (1 ${ }^{\text {st }}$ ed.). São Paulo. Edições 70.

CDC, Centers for Disease Control. (2016). Surveillance for foodborne disease outbreaks. Retrieved from https://www.cdc.gov/fdoss/annual-reports/index.html.

Clayton, D. A., \& Griffith, C. J. (2008). Efficacy of an extended theory of planned behaviour model for predicting caterers' hand hygiene practices. International Journal of Environmental Health Research, 18(2), 83-98. https://doi.org/10.1080/ 09603120701358424.

Da Cunha, D. T., Braga, A. R. C., Passos, E. D. C., Stedefeldt, E., \& De Rosso, V. V. (2015). The existence of optimistic bias about foodborne disease by food handlers and its association with training participation and food safety performance. Food Research International, 75, 27-33. https://doi.org/10.1016/j.foodres.2015.05.035.

Da Cunha, D. T., De Oliveira, A. B. A., Saccol, A. L. de F., Tondo, E. C., Silva, E. A., Ginani, V. C., et al. (2014). Food safety of food services within the destinations of the 2014 FIFA World Cup in Brazil: Development and reliability assessment of the official evaluation instrument. Food Research International, 57, 95-103. https://doi. org/10.1016/j.foodres.2014.01.021.

Da Cunha, D. T., De Rosso, V. V., Pereira, M. B., \& Stedefeldt, E. (2019). The differences between observed and self-reported food safety practices: A study with food handlers using structural equation modeling. Food Research International, 125, 108637. https://doi.org/10.1016/J.FOODRES.2019.108637.

Da Cunha, D. T., De Rosso, V. V., \& Stedefeldt, E. (2018). Food safety performance and risk of food services from different natures and the role of nutritionist as food safety leader. Ciência \& Saúde Coletiva, 23(12), 4033-4042. https://doi.org/10.1590/1413812320182312.21042016.

Da Cunha, D. T., Fiorotti, R. M., Baldasso, J. G., De Sousa, M., Fontanezi, N. M., Caivano, S., et al. (2013). Improvement of food safety in school meal service during a long-term intervention period: A strategy based on the knowledge, attitude and practice triad. Food Control, 34(2), 662-667. https://doi.org/10.1016/j. foodcont.2013.06.003.

Da Cunha, D. T., Stedefeldt, E., \& De Rosso, V. V. (2014). The role of theoretical food safety training on Brazilian food handlers' knowledge, attitude and practice. Food Control, 43, 167-174. https://doi.org/10.1016/j.foodcont.2014.03.012.

De Andrade, M. L., Rodrigues, R. R., Antongiovanni, N., \& Da Cunha, D. T. (2019). Knowledge and risk perceptions of foodborne disease by consumers and food handlers at restaurants with different food safety profiles. Food Research International, 121, 845-853. https://doi.org/10.1016/j.foodres.2019.01.006. 
De Andrade, M. L., Stedefeldt, E., Zanin, L. M., \& Da Cunha, D. T. (2020). Food safety culture in food services with different degrees of risk for foodborne diseases in Brazil. Food Control, 112, 107152. https://doi.org/10.1016/j.foodcont.2020.107152.

De Boeck, E., Jacxsens, L., Vanoverberghe, P., \& Vlerick, P. (2019). Method triangulation to assess different aspects of food safety culture in food service operations. Food Research International, 116, 1103-1112. https://doi.org/10.1016/j. foodres.2018.09.053.

Defense Ministry of Brazil. (2015). Resolution no. 753 of the $30^{\text {th }}$ of March 2015. Approves the food safety regulation of the armed forces. http://bdex.eb.mil. br/jspui/handle/123456789/192/ Accessed 15th March 2020.

EFSA, European Food Safety Authority. (2018). The European Union summary report on trends and sources of zoonoses, zoonotic agents and food-borne outbreaks in 2017 EFSA Journal, 16(12), 262. https://doi.org/10.2903/j.efsa.2018.5500.

Ehiri, J. E., Morris, G. P., \& McEwen, J. (1997). Evaluation of a food hygiene training course in Scotland. Food Control, 8(3), 137-147. https://doi.org/10.1016/S0956 7135(97)00005-4.

Flynn, K., Villarreal, B. P., Barranco, A., Belc, N., Björnsdóttir, B., Fusco, V., et al. (2019) An introduction to current food safety needs. Trends in Food Science \& Technology, 84 1-3. https://doi.org/10.1016/j.tifs.2018.09.012.

Fujisaki, K., Shimpo, M., \& Akamatsu, R. (2019). Factors related to food safety culture among school food handlers in tokyo, Japan: A qualitative study. Journal of Foodservice Business Research, 22(1), 66-80. https://doi.org/10.1080/ 15378020.2018.1546075.

GFSI. (2018). A culture of food safety - a position paper from the global food safety initiative (GFSI). Retrieved from https://www.mygfsi.com/files/GFSI_A_Cultu re Of Food Safety SUMMARY.pdf.

Griffith, C. J. (2014). Developing and maintaining a positive food safety culture (1 $1^{\text {st }}$ ed.) Doncaster: Highfield.

Griffith, C. J., Jackson, L. M., \& Lues, R. (2017). The food safety culture in a large South African food service complex: Perspectives on a case study. British Food Journal, 119 (4), 729-743. https://doi.org/10.1108/BFJ-11-2016-0533.

Griffith, C. J., Livesey, K. M., \& Clayton, D. (2010a). The assessment of food safety culture. British Food Journal, 112(4), 439-456. https://doi.org/10.1108/ 00070701011034448

Griffith, C. J., Livesey, K. M., \& Clayton, D. A. (2010b). Food safety culture: The evolution of an emerging risk factor? British Food Journal, 112(4), 426-438. https:// doi.org/10.1108/00070701011034439.

Health Ministry Brazil. (2019). Resolution no. 331 of the 23rd of December 2019. Establishes microbiological standards and its application. http://portal.anvisa.gov. br/documents/10181/4660474/IN_60_2019_.pdf/8b764b8f-5172-4bfc-a855-bc73 972ee96f/, 15th March 2020.

Health Ministry of Brazil. (2004). Resolution no. 216 of the 15th of September 2004 Establishes the technical regulation of good manufacturing practices to food services. http://portal.anvisa.gov.br/documents/33916/388704/RESOLU\%25C3\% 2587\%25C3\%2583O-RDC\%2BN\%2B216\%2BDE\%2B15\%2BDE\%2BSETEMBRO \% 2BDE\%2B2004.pdf/23701496-925d-4d4d-99aa-9d479b316c4b/ Accessed 15th March 2020.

Health Ministry of Brazil. (2014). Curso de Boas práticas de Manipulação em serviços de Alimentação Accessed 20th Mach 2020 https://www.escolavirtual.gov.br/curs $\mathrm{o} / 287 /$.

Hult, M., \& Lennung, S. (1980). Towards a definition of action research: A note and bibliography. Journal of Management Studies, 17(2), 241-250. https://doi.org/ 10.1111/j.1467-6486.1980.tb00087.x.

Lin, N., \& Paez, P. (2020). Leading by example: A three-wave sequential mixed method food safety study. International Journal of Hospitality Management, 87, 102463. https://doi.org/10.1016/j.ijhm.2020.102463.

Luning, P. A., Chinchilla, A. C., Jacxsens, L., Kirezieva, K., \& Rovira, J. (2013). Performance of safety management systems in Spanish foodservice establishments in view of their context characteristics. Food Control, 30(1), 331-340. https://doi.org/ 10.1016/j.foodcont.2012.06.040.

Luning, P. A., \& Marcelis, W. J. (2020). Food quality management: Technological and Managerial principles and practices ( $\left.2^{\text {nd }} \mathrm{ed}.\right)$. Wageningen: Wageningen Academic Publishers.
McFarland, P., Checinska Sielaff, A., Rasco, B., \& Smith, S. (2019). Efficacy of food safety training in commercial food service. Journal of Food Science, 84(6), 1239-1246. https://doi.org/10.1111/1750-3841.14628.

Medeiros, C. O., Cavalli, S. B., Salay, E., \& Proença, R. P. C. (2011). Assessment of the methodological strategies adopted by food safety training programmes for food service workers: A systematic review. Food Control, 22(8), 1136-1144. https://doi. org/10.1016/j.foodcont.2011.02.008.

Mertens, D. M. (2010). Research and evaluation in education and Psychology: Integrating Diversity with quantitative, qualitative, and mixed methods ( $3^{\text {rd }}$ ed.). Sage Publications.

Nyarugwe, S. P., Linnemann, A., Hofstede, G. J., Fogliano, V., \& Luning, P. A. (2016). Determinants for conducting food safety culture research. Trends in Food Science \& Technology, 56, 77-87. https://doi.org/10.1016/j.tifs. 2016.07.015.

Nyarugwe, S. P., Linnemann, A. R., \& Luning, P. A. (2020). Prevailing food safety culture in companies operating in a transition economy - does product riskiness matter? Food Control, 107, 106803. https://doi.org/10.1016/j.foodcont.2019.106803.

Raats, M. M., Sparks, P., Geekie, M. A., \& Shepherd, R. (1999). The effects of providing personalised dietary feedback. A semi-computerised approach. Patient Education and Counseling, 37(2), 177-189. https://doi.org/10.1016/s0738-3991(98)00114-1.

Rennie, D. M. (1994). Evaluation of food hygiene education. British Food Journal, 96(11), 20-25. https://doi.org/10.1108/00070709410074650.

Saccol, A. L. D. F., Hecktheuer, L. H., Richards, N. S., \& Stangarlin, L. (2006). Lista de avaliação para boas práticas em serviços de alimentação: RDC 216/2004-Anvisa.

Stedefeldt, E., Zanin, L. M., Da Cunha, D. T., De Rosso, V. V., Capriles, V. D., \& Saccol, A. L. de F. (2015). The role of training strategies in food safety performance: Knowledge, behavior, and management. In Food safety: Emerging issues, Technologies and systems (pp. 365-394). https://doi.org/10.1016/B978-0-12-800245-2.00018-6.

Stedefeldt, E., Zanin, L. M., Saccol, A. L. de F., Tondo, E. C., Ginani, V. C., Silva, E. A. da., Jr., et al. (2017). Semiquantitative and qualitative assessment for determination of sanitary risk in food service establishments. In R. V. Ravishankar, \& J. A. Bai (Eds.), Food safety and protection (pp. 3-28). https://doi.org/10.1201/ 9781315153414.

Thaivalappil, A., Waddell, L., Greig, J., Meldrum, R., \& Young, I. (2018). A systematic review and thematic synthesis of qualitative research studies on factors affecting safe food handling at retail and food service. Food Control, 89, 97-107. https://doi.org/ 10.1016/j.foodcont.2018.01.028.

Yiannas, F. (2015). Food safety = behavior 30 proven techniques to enhance employee compliance ( $1^{\text {st }}$ ed.). New York: Springer.

Young, I. A. N., Greig, J., Wilhelm, B. J., \& Waddell, L. A. (2019). Effectiveness of food handler training and education interventions: A systematic review and metaanalysis. Journal of Food Protection, 82(10), 1714-1728.

Young, I., Waddell, L. A., Wilhelm, B. J., \& Greig, J. (2020). A systematic review and meta-regression of single group, pre-post studies evaluating food safety education and training interventions for food handlers. Food Research International, 128, 108711. https://doi.org/10.1016/j.foodres.2019.108711.

Yu, H., Neal, J., Dawson, M., \& Madera, J. M. (2018). Implementation of behavior-based training can improve food service employees' handwashing frequencies, duration, and effectiveness. Cornell Hospitality Quarterly, 59(1), 70-77. https://doi.org/ $10.1177 / 1938965517704370$.

Yu, H., Sirsat, S. A., \& Neal, J. A. (2019). Linking food safety training with whistleblowing: The mediation roles of job satisfaction and self-efficacy. International Journal of Contemporary Hospitality Management, 31(1), 141-160. https://doi.org/ 10.1108/ijchm-10-2017-0689.

Zanin, L. M., Da Cunha, D. T., De Rosso, V. V., Capriles, V. D., \& Stedefeldt, E. (2017). Knowledge, attitudes and practices of food handlers in food safety: An integrative review. Food Research International, 100, 53-62. https://doi.org/10.1016/j. foodres.2017.07.042.

Zanin, L. M., Da Cunha, D. T., Stedefeldt, E., \& Capriles, V. D. (2015). Seafood safety: Knowledge, attitudes, self-reported practices and risk perceptions of seafood workers. Food Research International, 67, 19-24. https://doi.org/10.1016/j. foodres.2014.10.013.

Zanin, L. M., Luning, P. A., Da Cunha, D. T., \& Stedefeldt, E. (2021). Influence of educational actions on transitioning of food safety culture in a food service context: Part 1 - triangulation and data interpretation of food safety culture elements. Food Control, 119, 107447. https://doi.org/10.1016/j.foodcont.2020.107447. 